\title{
The effects of curing technology on the rheological and organoleptic features of meat products
}

\author{
Zoltán Tudós $^{1}$ - Anita Vass ${ }^{2}$ - Erika Hanczné Lakatos ${ }^{1}$ - Balázs Ásványi ${ }^{1}$ \\ ${ }^{1}$ Széchenyi István University, Faculty of Agriculturaal and Food Sciences, Department of Food Sciences, Mosonmagyaróvár, Hungary. \\ ${ }^{2}$ Galen Bio Kft, Mosonmagyaróvár, Hungary \\ tudos83@gmail.com
}

SUMMARY

\begin{abstract}
Meat products are important staple foodstuffs owing to their high protein, vitamin and mineral content. Meat plants do not only use traditional production technologies but also develop methods that preserve the nutritional value of meat or improve the texture and organoleptic features of meat products. These features play an important role in the consumer society. Consumers first meet the external features of meat and this experience influences their decisions. Our analyses compared a traditional and a new curing procedure. Besides organoleptic inspections, we analysed texture with a CT3 type Texture Analyser to obtain quantified information on the condition of meat samples in the various curing phases. We used our results to compare traditional and new curing procedures.
\end{abstract}

Keywords: Texture analyser, organoleptic analyses, meat products, curing technology

\section{INTRODUCTION}

Humankind has been eating various types of meat since time immemorial, and meat is a staple food owing to its varied physiological effects. In addition to its high protein and amino acid content, it is also an important source of vitamins and minerals.

The meat industry has developed various preservation technologies to preserve the original condition and nutritional value of meats and meat products. These technologies can affect the texture and organoleptic features of meat and meat products.

Nowadays, modern texture analysers are available to measure changes in meat product texture and features. Besides instrumental texture analysis, it is also expedient to analyse meat products organoleptically. This provides a comprehensive picture of the texture, taste, colour, fragrance and exterior features of meat products.

Rheology is a relatively new discipline, as it became independent in the early 1900s. Before that, it was regarded as a subfield of mechanics. It became a discipline by its own right through the scientific works of Eugene Cook Bingham in 1916 and H. Green in 1919 (László, 2003). Foodstuff texture can be rated in two ways, with organoleptic analysis and instrumental measurements, i.e. texture analysers. The advantage of applying texture analysers in the food industry is that their measurements are easy to repeat as well as timeand cost-efficient (Zeke, 2015). Our foodstuffs are complex chemical and physical systems and undergo various mechanical impacts (shredding, milling, mixing, thermal treatment, etc.) of their production technologies. These impacts greatly affect the structural and texture features of foodstuffs because they cause tensions and, consequently, deformations in the product. Food rheology analyses the connection between deformations caused by forces and time-, temperature- and pressure-dependency in foodstuffs (Figler, 2015). The mechanical features having a determining effect on texture can be divided up to five primary factors and three secondary factors which are influenced by the primary ones. The primary factors are hardness, adhesion, viscosity, cohesion and elasticity; the secondary factors are expressed through the chewability/chewiness and toughness of the foodstuff (Szczesniak, 1963).

Organoleptic analyses are a subfield of food analytics and the applied organoleptic instrument is the human itself (Rothe, 1978). A basic type of descriptive and assessing methods is the direct scoring method. The reviewer applying this scoring method establishes the features of the reviewed foodstuff based on a general impression obtained through smelling, tasting, chewiness and sight and gives a score to each of them. The method described by Plank in 1943 was not fully reliable in the beginning because the features of the reviewed product were weighed in the same way, independently from the product itself. However, the sodeveloped 20-score method was modernised in the late $1900 \mathrm{~s}$ and is, therefore, applied in practice as an organoleptic foodstuff analysis method in several European countries (Plank, 1943; Neul, 1985). The 20score weighting factor review method now covers all commercial foodstuffs and luxury articles. (Molnár, 1991). One of the most important requirements for the right application of the scoring method is that the number of reviewers should be at least between 3 and 5 . The reviewers score the analysed products based on a rating scale the scores of which range from 1 to 5 in the 20-score system. An attribute belongs to each of the five scores and refers to the products quality. The most common attributes are the expressions

- "unsatisfactory" or "inadequate"

- "less satisfactory" or "just adequate"

- "satisfactory" or "medium"

- "good"

- and "excellent".

The scores belonging to the five expressions above cover the rating scale of the analysis from the attribute "inadequate" (score 1) to "excellent" (score 5). 
The rating scale of these five expressions is, however, not applicable in itself. The meanings and requirements of the five expressions must be clearly specified and defined in every case (Molnár, 1991).

Review result assessment also requires that the weighting factors of feature groups are specified (Molnár, 1991).

\section{OBJECTIVES}

Our tests compared the rheological and organoleptic features of meat products made with traditional and ultrasonic assisted curing procedures. Our measurements focused on analysing the differences in the texture and organoleptic features of the products made with the two technologies.

\section{MATERIALS AND METHODS}

The two analysed production technologies were traditional curing and ultrasonic assisted curing procedures. Texture analysis samples from the meat products were taken on the $3^{\text {rd }}, 4^{\text {th }}, 5^{\text {th }}, 6^{\text {th }}$ days of the curing and ageing process and, in some cases, during the subsequent smoking phase. We analyzed English Bacon, Belly Bacon, "Császár" Bacon, skin-on loin, spareribs, boneless spareribs, boneless pork butt. We also performed organoleptic analyses besides the texture analyses.

Product texture was analysed with a CT3 type Texture Analyser manufactured by Brookfield (Figure 1) in TPA (Texture Profile Analysis) mode, in two cycles, with three types of probe heads (cylindrical, conical with a $60^{\circ}$ angle and blade) and in 6 parallels. Mandatory measurement parameters were meat sample size and shape, meat penetration depth $(\mathrm{mm})$ and its load value $(\mathrm{g})$. In preparing the meat samples ready for analysis, we cut $2 \mathrm{~cm}$ thick and $1.25-\mathrm{cm}$-diameter cylinders and approximately $2 \mathrm{~cm}$ high and $2 \mathrm{~cm}$ wide cubes from them. Before measuring, we recorded these data in the TexturePro V1.6 Build 26® software of the texture analyser. The measurements provided data on the typical hardness, resilience, peak tension, adhesion strength, elasticity, cohesion and chewiness. We analysed the obtained data and compared the meat products made with the two different procedures with a paired student test as statistical method.

We performed the organoleptic analysis of the samples with the 20-score weighting factor review of meat products.

According to consumer habits, we cut finger-thick slices from the samples for organoleptic review and assigned identifiers to them.

We ranked the reviewed samples according to fragrance and taste intensity by considering the characteristics of the product group.
Figure 1: Texture Analyser by TA2/1000 head

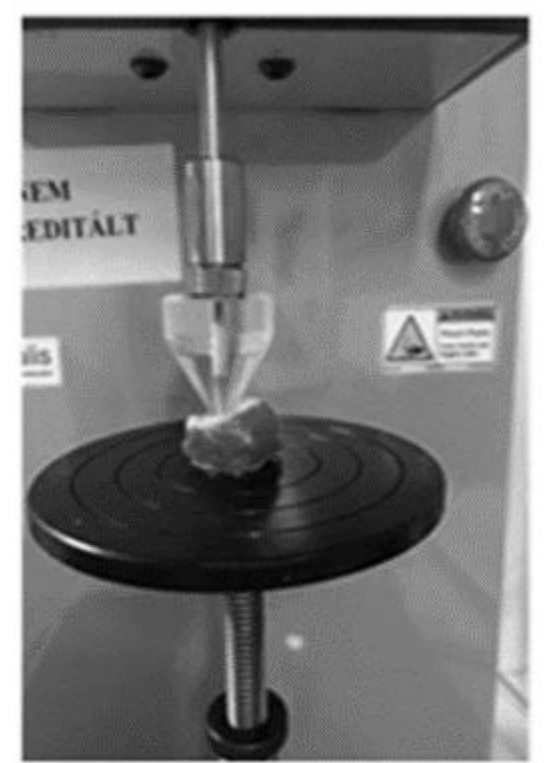

Source: My recording

\section{RESULTS}

In terms of hardness, we found significant differences between products made with the two production technologies in 5 instances per probe head. In terms of the two resilience parameters, we found significant differences, and ultrasound-treated products were better in 5 instances per probe head, products made in the traditional way were better 10 instances per probe head. In terms of peak tension, we found differences and the ultrasound-treated products were better in 3 instances per probe head, the control meat products were better in 2 instances per probe head. In terms of adhesion strength, ultrasound-treated products were better in 6 instances, control products were better in 2 instances per probe head. In terms of elasticity, significant differences between the products made with the two different technologies were found in 4 instances. In terms of cohesion, significant differences were found in 5 instances. Finally, in terms of chewiness, we found significant differences and the ultrasound-treated products were better in 2 instances, the products made in the traditional way were better in 4 instances.

Figures 2-4 show the relations among the average chewiness, hardness and elasticity values of ultrasound-treated and control product samples of bacon after smoking. 
Figure 2: General chewiness values of ultrasound-treated and control samples of bacon after smoking during the TPA measurement

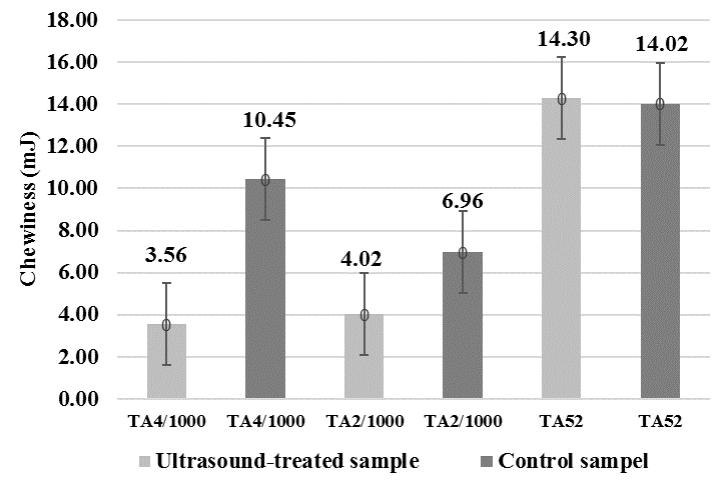

Figure 3: General hardness values of ultrasound-treated and control samples of bacon after smoking during the TPA measurement

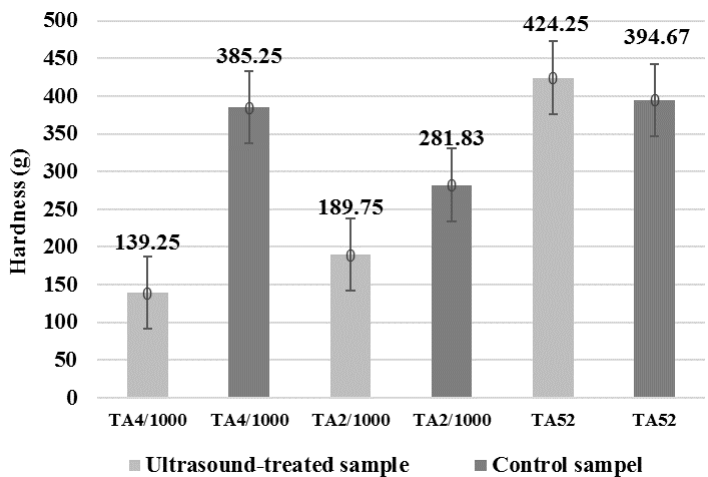

Figure 4: General elasticity values of ultrasound-treated and control samples of bacon after smoking during the TPA measurement

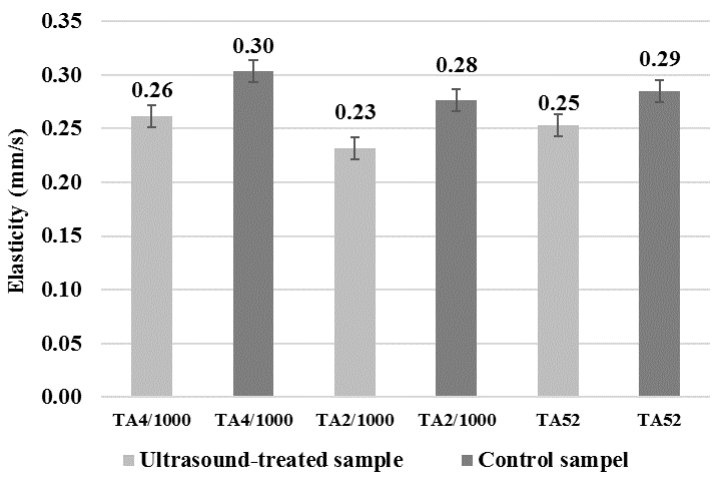

The above charts show the clear difference between the ultrasonic and traditional curing procedures of the chosen meat product, i.e. the general chewiness, hardness and elasticity values (obtained with three different probe heads) of the product were lower than those of the control sample in all three cases when the first two probe heads were used and in one case when the last probe head was used.
We analysed the organoleptic features of the control and ultrasound-treated samples taken from the six meat products of the manufacturer.

We classified the meat products made with the two different technologies into "excellent", "good" and "medium" categories based on their rating scores. Figure 5 shows the ratings of meat products made with traditional and with ultrasonic curing.

\section{Figure 5: Quality distribution of the products reviewed according to the five criteria}

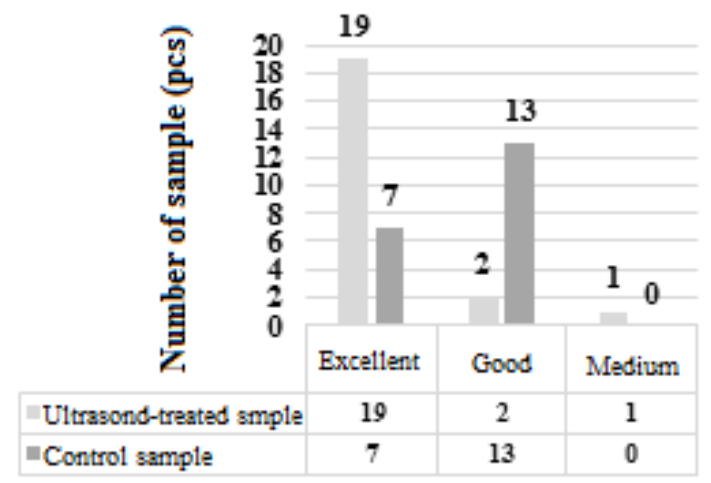

Organoleptic quality category

The column chart of Figure 5 clearly shows the distribution of reviewed meat products among rating categories. The proportion of excellent products is much higher among those having received ultrasonic treatment than those made with the traditional curing procedure. Another visible difference is that in the "good" category, which is one category below "excellent", is mostly occupied by control products and not ultrasound-treated samples. The percentage distribution of the "excellent" and "good" quality categories of ultrasound-treated and control samples is illustrated in Figures 6 and 7 below.

Figure 6: Distribution of "excellent" quality categories for the Ultrasound-treated and Control sample

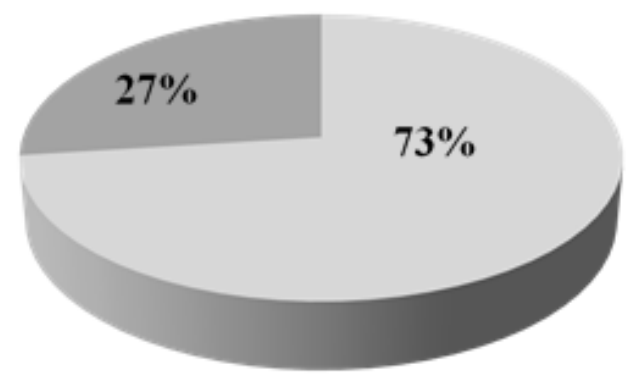

Ultrasound-treated sample ॥ Control sample 
Figure 7: Distribution of "good" quality categories for the Ultrasound-treated and Control sample

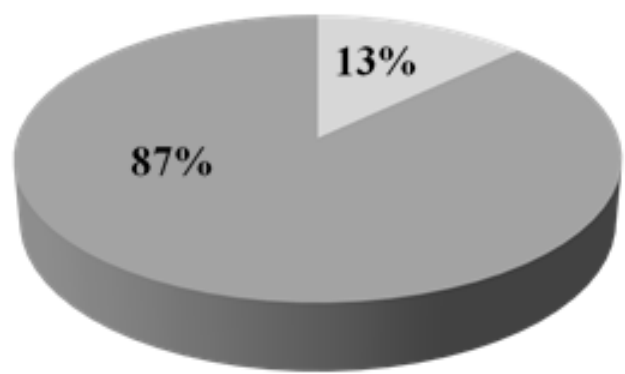

Ultrasound-treated sample $\mid$ Control sample

\section{DISCUSSION}

After the texture and organoleptic analyses of meat products made with the two curing procedures and the valuation of the analysis results, we have drawn the following conclusion.

Based on the statistical data analysis of the TPA parameters of meat products' intrinsic features in texture analyses and all the analysed product types, the curing technology involving ultrasound treatment did not meant negative or outstandingly positive change in comparison with products made only with the traditional curing procedure.

However, according to Figures 2, 3 and 4 of the results, the curing procedure involving ultrasonic treatment produced more positive texture features for bacon, because this product was less chewy and hard than the control product.

Based on the texture analysis of ultrasound-treated and control products, we have concluded that ultrasonic treatment in the curing solution does not cause any negative change of the product. Its explicitly positive effect, however, depends clearly on the product itself.

Based on data produced by the organoleptic analysis, the proportion of the analysed products rated as "excellent" and "good" indicated a difference between ultrasound-treated and control samples. Results shown in Figures 6 and 7 indicate that threequarters of the ultrasound-treated sample was rated "excellent", but only one-quarter of the control sample was rated such. However, it was also apparent that $87 \%$ of the "good" category were control products.

In summary, we can say that the curing procedure combined with ultrasound treatment produced absolutely positive organoleptic (cut surface, consistency/texture, fragrance, colour) features for the products analysed; therefore, this new curing technology is recommended without doubt to achieve the positive effects of organoleptic features. Although the texture is the same, the shorter curing time of ultrasound-treated products could imply economically advantageous changes eventually.

\section{ACKNOWLEDGEMENTS}

This paper is supported by the EFOP-3.6.2-162017-00012 project "Developing a functional, healthy and safe food product chain model from field to table in a thematic research network". The project was funded by the European Union and co-financed by the European Social Fund.

\section{REFERENCES}

Figler, M. (2015): Élelmiszer-tudományi ismeretek, Medicina Könyvkiadó Zrt., Budapest, p. 129.

László, P. (2003): Reológia. in: László, P. (Szerk.): Élelmiszerfizika I. (Hidrodinamika, Reológia, Fénytan). Budapest: BKÁE Kertészettudományi Kar, jegyzet, p. 165., pp.40-45., 51-68.

Molnár, P. (1991): Élelmiszerek érzékszervi vizsgálata, Akadémia Kiadó, Budapest, pp. 11-16, 151-152, 158-173, 319-320, 351358.

Neul, P. (1985): DLG-Prüfschema in neuer Form. Flüssiges Obst p.2, p.52, p.77.
Plank, R. (1943): Vorratspflege und Lebensmittelforschung VI, p.4. Rothe, M. (1978): Einführung in die Aromaforschung, AkademieVerlag, Berlin.

Szczesniak, A. S. (1963): Classification of Textural Characteristics, Journal of Food Science, vol. 28. p.385.

Zeke, I. Cs. (2015): Fagyasztott élelmiszer-emulziók stabilitásának vizsgálata, Doktori értekezés, Budapesti Corvinus Egyetem, pp.43-45. 